\title{
HALAL TOURISM: AN OPPORTUNITY FOR THE GLOBAL TOURISM INDUSTRY
}

\author{
Paolo Pietro Biancone, Silvana Secinaro, Maha Radwan, Mohamad Kamal
}

Department of Management, University of Turin, Italy

\begin{abstract}
Halal tourism has become the focus of attention in worldwide, while European and American countries are trying to expand and attract Muslim tourists. In recent years, Halal tourism has been widely seen as one of the strongest export markets for this type of tourism. This new tourist style is meant for hotels and resorts that are keen to not offer any programs, meals, food or activities that are contrary to Islamic law. This study tries to construct a framework for best practices in the halal tourism industry through a qualitative approach by comparing 6 developed halal tourism countries 3 OIC (Organization of Islamic Cooperation) and 3 non-OIC the analysis studied that ( Malaysia, UAE, Indonesia, Singapore, Thailand, and the UK) are having the best practices in the halal tourism industry. The study contributes by proposing an index for the best practices in order to access tourism halal market by countries that are not developed yet in this industry for example Italy.
\end{abstract}

Key-words: Halal tourism, Ethical tourism, Tourism Industry

\section{Introduction}

Tourism has always been a very important sector of the economy, especially in countries that have certain characteristics (beauty of the landscape, monuments, gastronomic products, highly characteristic customs and culture, etc ...); all the countries with a strong tourist vocation have created ad hoc campaigns to attract visitors, tour operators always try to anticipate the market by identifying new destinations and new objectives. Starting from the Economic point of view, tourism plays an important role in contributing to economic growth, creating jobs, increasing productivity and income. Tourism is an important added value to the economy of the whole country (Durbarry, 2004). It also promotes intercultural understanding and well-being among the countries (Yu \& Lee, 2014). In summary, the development of this sector can be instrumental to the improvement of the conditions existing in the country that favors and develops the receptive activity in the broadest sense.

International tourist flows have increased significantly in recent decades and are expected to increase further in the near future (UNWTO, 2017). In the aggregate of tourist flows all over the world, it is observed that the Halal tourism (tourism that respects the principles of Islam) is developing a lot in these years. Muslim consumers, who are younger on average, educated and 
provided with more sources of income, have shown increasing interest in global travel and vacations (Mastercard \& Crescentrating, 2017). This trend is also growing in correlation with the phenomenon in which, in many countries, operators in the sector are increasingly attentive to the satisfaction of the standards demanded by Islamic tourists, to offer them adequate solutions and, finally, to attract them in every respect (El-Gohary, 2016).

Here, at this point, it is necessary to clarify the terms of the particular position of users of this type of tourism, it is necessary to know the ethical-religious-cultural characteristics of the tourists interested in this article. Halal tourism is, therefore, all pervaded by the ethical sphere because the tourist necessarily contemplates the provisions of Shariah and undertakes to respect and observe - even in time and on the occasion of the trip - all the behavioral rules dictated by the religion of belonging. For this reason, it is stressed that all that is allowed according to the dictates of Shariah, or Islamic law, is called Halal (Jaelani, 2017). For Halal it is not only the connotation of food and clothes, or cosmetics, but also with reference to every aspect of tourism and holidays (Thomson Reuters \& Dinar Standard, 2016).

The journey in Islam is mainly linked to the ritual of pilgrimage to Mecca (Jafari \& Scott, 2014), but Islam stimulates the journey also for business, for learning and for the knowledge of other civilizations. The limit imposed on all journeys is that they are Halal, so that they fall into one of these types of objectives and therefore comply with all the requirements defined by the ethics of a Muslim. We immediately think of the limits in terms of food, with the prohibition of pork and alcohol, as well as all non-Halal meat. We think of the needs of families and of women in particular of being able to remain without a veil in familiar environments or only women; be able to access swimming pools, massage centers, where there are exclusively women and vice versa for men (SESRIC, 2017).

The travel sector including the Halal one contribute significantly to the improvement of global gross domestic product (GDP), determine new opportunities for economic growth, with reference to the travel, tourism and hospitality sectors all over the world. Halal travelers constitute a population that offers huge opportunities (COMCEC, 2016), they are groups of families or individuals who have specific requirements regarding Halal tourism, easily satisfying requirements and without the need for large investments by commercial operators in the hospitality sector.

The objective of the research: - This article aims to identify a new business opportunity in the world tourism sector represented by Islamic consumers, - Focus on the relationship between OIC and non-OIC countries regarding the Halal Tourism sector, In particular, the best Halal destinations, - Analyze the most developed countries in the Halal tourism sector in order to achieve an index of the best practices for accessing such market developing a proposal for destinations or countries that need to access such market. 
Therefore, after the section of the introduction, the work is divided into four main sections. The first section concerns the literature review for many scientific articles and reports which explained the concept of Islamic religion and the most important sources of legislation governing the economic process, including tourism and the importance and development of the global Islamic economy in recent times and then the focus was on Global tourism sector and its relation with Halal tourism. The conversation was centered on the stages of development in general for the tourism sector and its contribution to the global economy. It was mentioned some definitions of Halal tourism and the most important characteristics and conditions that distinguish Halal tourism from other types. In the last was explained Halal travel market and its potential in the present and future. In the second section was introduced the methodology where it was used the qualitative approach to compare between two cases (OIC and non-OIC countries) through the identification of similarities and differences according to the basic standards in recent years regarding the Halal Tourism sector, In particular, the best Halal destinations. In the third section is used the discussion \& finding for 3 variables: - Top Halal tourism expenditure source countries, - Top 10 OIC and non-OIC Halal tourism destinations, - Halal tourism rank for World's top tourism destinations. In the fourth and last section the conclusion and advances in which it has been said that Halal tourism has shown that it is a new business opportunity in the world tourism sector represented by Islamic consumers and the results show that the OIC countries outweigh the countries OIC in terms of spending and welcoming Muslim tourists in this sector. In the end, the study shows that there are countries like Italy and Mexico are still a destination not very frequented and with a weak structure of Muslim friendly services.

\section{Literature Review}

Islam is an Abrahamic religion centred on the Quran (the main and sacred book of Islam). The Islamic economic system is essentially regulated by the Shariah is translated as Islamic law. The main source of Shariah is the Quran, and it the behaviours of a believer's life. Shariah indicates the rules and precepts that every Muslim must observe in every field of action (religious, sociopolitical, cultural and economic) and that must follow everywhere both in its relationship with God and in acting towards other men (Biancone, 2017). Alongside Quran, there are three sources of Shariah (Haron, 2009): the Hadith (is a set of traditions and rules deriving from the prophet's behaviour and words), the Ijma (Consensus of the Muslim scholars) and the Qiyas (Deductive analogy). Ijma which refers to the collective consensus of Islamic jurists on particular instances or problems. The Qiyas comes from reasoning by analogy that allows the combination of revelation with human reason (Milliot \& Blanc, 1987). The original meaning of Qiyas is "to measure" or "to trace similarities between two things" (Ali, 1951).

The Islamic economy is growing strongly and contributes increasingly to the global economic growth. The Halal industry represents an ever-expanding reality and involves every sector, from food to fashion, from pharmaceuticals and cosmetics to media, leisure and tourism. According to the Global Islamic Report 2016, the Islamic economy was valued at 1.9 trillion dollars in 2015 (Thomson Reuters \& Dinar Standard, 2016). 


\section{Global Tourism Sector \& Halal Tourism}

In the Grand Tour period, from the seventeenth century, tourism was an elite phenomenon, destined for a few. During the Tour, young people learned about the politics, culture, art, and antiquities of European countries (Haynes, 2010). Around the '50s -' 60s, the tourism sector has seen a remarkable development, with the birth of mass tourism that has involved all walks of life (Buhalis \& Costa, 2006). Since the early 1980s, globalization has profoundly changed the tourism that has moved on to global tourism. The notable increase in air traffic and economic and internet development have led to an increase in unprecedented tourist activities and the discovery of previously unattainable destinations (Bianchi, 2002).

The recent European colonization of some of the Islamic countries led to the development of many areas, most notably the tourism sector. Colonial interaction led to the development of the transport, residence and travel sector by Europe's cultural elite. Thomas Cook and his son contributed to the development of tourism in the Middle East in the 19th century. After World War II, and with the introduction of modern transport such as aircraft and the need for economic development led to the development of tourism across the Islamic world (Jafari \& Scott, 2014).

It is difficult to give a uniform definition of the concept of tourism. According to the (UNWTO , 2017), "Tourism comprises the activities of persons travelling to and staying in places outside their usual environment for not more than one consecutive year for leisure, business and other purposes not related to the exercise of an activity remunerated from within the place visited." Therefore, The tourist is a person who moves for a short period of time (more than 24 hours) from the usual place of residence to a vacation spot, more or less distant, to satisfy his personal pleasure. In contemporary life, around one billion people travel annually in the world for tourism (Duman, 2012).

On a global scale, it is estimated that tourism represents today $10 \%$ of the gross domestic product, one occupied on 11 and $7 \%$ of world exports. In 1950 there were 25 million international tourists, in 2015 there were 1186 million and in 2030 it is expected that 1.8 billion will be. The number of domestic tourists worldwide is estimated at between 5 and 6 billion (UNWTO, 2016) within the tourism sector, the Halal travel market is one of the most profitable and growing market segments (Razalli, Abdullah, \& Hassan, 2012)

\section{Halal Tourism: Definition \& Characteristic}

The tourism industry uses a variety of terms to describe the products and services for Muslim travellers. In the literature, academics use more the terms "Halal Tourism" and "Islamic Tourism" in reference to products and tourism services that address the needs of Muslim travellers. In a previous study commissioned by (COMCEC, 2016), Muslim-friendly tourism was equated with Halal tourism and defined as "Muslim travellers who do not wish to compromise their basic faith-based needs while travelling for a purpose, which is permissible". Initially, the academic concept of tourism Muslim friendly was defined by analyzing all the elements that 
comprise tourism and in particular its impact on society. (AKYOL \& KILINÇ, 2014) link the term Muslim friendly to the needs and services based on faith and belong to a niche market such as Halal hotels, Halal transport (Halal airlines), Halal restaurants, tourist packages and Halal finance. Therefore, Halal tourism consists of several sectors that are connected to each other.(Chookaew, chanin, Charatarawat, Sriprasert, \& Nimpaya, 2015) defines Halal tourism as offering tourist packages and destinations particularly designed to meet Muslim needs. Muslim tourism based on Islamic teaching that encourages individuals, especially women and children, to travel with their muhrim, that is, an individual linked by a blood relationship that can provide them with security (Osman et al., 2015). The definitions of "Tourism Halal" underline the idea of compliance with Shariah; many academics define Halal tourism as "any tourist object or action that is allowed according to Islamic teachings in the tourism industry" (M. Battour \& Ismail, 2016).

To be considered Halal or Shariah-compliant, tourism products and services must possess numerous attributes. For the food sector, it is much easier to establish the characteristics that the products must possess in order to be considered compliant with the sacred law, as opposed to the tourist services. Theoretically, a shariah-compliant hotel should be free of alcohol and any form of entertainment that is incompatible with Islamic principles, as well as being equipped with separate facilities for men and women. In addition, some scholars argue that the aspects related to financial and human resources, responsible for the management of hotel facilities, should also respect Islamic principles.(Razalli et al., 2012),(Warde, 2000).

The Muslim friendly measures that can be adopted in a hotel can be summarized in the following main points: Availability of food and Halal kitchens; Prayer mat with a copy of the Quran in the room with the Directorate of the Qibla; TV programs suitable for the family; No alcoholic beverages in the mini-bar; Toilet adapted to the needs of Muslims; Presence of both male and female personnel to assist Muslim clients belonging to their sex, respectively; Muslim friendly dress code for the staff; Plans for women only or for families only; Different times of access to the pool or gym for women; Room for prayer (AKYOL \& KILINÇ, 2014), (Salleh, Hamid, Hashim, \& Omain, 2014).

According to (Mastercard \& Crescentrating, 2017), most of the Muslim faithful adhere to some of these needs, even if the level of importance attributed varies from faithful to faithful. In fact, the segmentation of Muslim travelers is not homogeneous. These needs can be divided into need to have, - good to have, - nice to have.

\section{Halal travel market and its potential}

Historically, Muslims are avid travellers, in fact, tourism in their society is welcome even if a recurring question concerns its lawfulness. In the Quran, the journey is considered a welcome action to know the history, society and other cultures and therefore useful to appreciate the infinite greatness of Allah (God in Islam) (Jafari \& Scott, 2014). For example 'Say, [Oh 
Muhammad, PBUH], "Travel through the land and observe how He began creation." (Al-Quran (29:20).

The concept of travel is deeply incarnated in the heritage of the Muslim people. From Hajj (Islamic pilgrimage), the pilgrimage of one of the five pillars of Islam (Abuznaid, 2006), to the story of one of the greatest travelers, Ibn Battuta, who traveled to Africa and Asia for almost 30 years, in which he brought back memories and observations of his journey (Battuta, 2004), to the scholar Muhammaad al-Bukhari who since his youth has traveled throughout the Islamic world to seek knowledge and gather the hadith (Sahih Al Bukhari, 2012), today the culture of travel is reflected in the tourism sector. Nowadays, the Islamic populations are however pushed to travel also for reasons of recreational, leisure, social, etc., the most important tourist attractions for Muslim tourists include: natural scenery, shopping, and modern atmosphere (M. M. Battour, Battor, \& Ismail, 2012).

The motivations that push Muslims to travel, as these are key information for the sector. Two major travel themes are identified: - Islamic motivations: for Muslims has always been an integral part of the Islamic faith, with a significant demand due to Hajj and Umrah. They can be classified into different areas: travelling to perform Hajj, Umra and other Islamic sites. Muslims also travel to strengthen the bond of silat al-rahim (Muslim fraternity) and for the promotion of Islam (tabligh), to seek knowledge and religious scientific research. -Generic motivations: Visit tourist places, shops and restaurants, to get to know and experience the culture of the place, visit friends, business trips, adventure, pleasure, personal business, increasing knowledge (Duman, 2012).

Islam is the second most widespread religion in the world after Christianity, made up of 1.6 billion faithful, who make up $23.4 \%$ of the world's population. Muslim population in the world should increase by about 35\% over the next 20 years, from 1.6 billion in 2010 to 2.2 billion by 2030 , with an average annual growth rate of $1.5 \%$. The other interesting data is the near parity (percentage) that will be reached in 2050 between Christians (2.9 billion) and Muslims (2.8 billion): together they will represent $60 \%$ of the world population. Overtaking, according to the report, will take place in 2070. The reasons for the demographic boom of Islam can be identified in the highest fertility rate at the international level: 3.1 children against 2.7 of Christian women. to widen the discussion to the other religions the Hindus show 2,3 children for every woman, the Jews 2,3 and the unbelievers 1,7 (PewResearchCenter, 2011),(Biancone, 2017).

The Muslim population has globally spent a total of \$ 151 billion on journeys in 2015 (excluding Hajj and Umrah), $11.2 \%$ of global market spending. This is a $4.9 \%$ growth compared to the previous year and is more than $3 \%$ of the global market. According to the study, it is estimated that in 2015 the revenues from the Muslim friendly travel services revolve around 24 billion dollars. By 2021, Muslim travel spending is estimated at $\$ 243$ billion, representing an $8.25 \%$ compound annual growth rate (CAGR) from 2015. The Muslim tourism market is the second largest in the world, immediately after China (168 billion dollars) and before the United States 
(with $\$ 146$ billion). In 2015, revenues were estimated for a total of 24 billion dollars related to Muslim friendly tourist services, in particular with reference to hotels, air travel and recreational activities (Thomson Reuters \& Dinar Standard, 2016)

\section{Methodology}

This study bears the imprint of (Almeida Garcia, 2014) regarding the analysis and comparisons of the way in which tourism policy has evolved in Spain and Portugal. The study covers an extensive period of time, enabling the similarities and differences between the two processes and the effects of the main factors involved to be highlighted phase by phase, the focus was on the role of tourism in economic development through the achievement of revenues as much as possible, and work on restructuring the tourism sector commensurate with developments and needs, where was used the Latin model of tourism development was used. The main objective of this work is to focus on the relationship between OIC and non-OIC countries regarding the Halal Tourism sector, In particular, the best Halal destinations, using the qualitative approach to compare between two cases (OIC and non-OIC countries) through the identification of similarities and differences according to the basic standards in recent years. Either we have adopted the method of this study that fits in some way with our research method. In the analysis, is identified the two cases in terms of the various criteria in which both are related and connected with Halal Tourism sector. The study, therefore, examined the practices and the processes performed in the two cases and linking them to the the highest visited countries in the world. In addition to these, there were additional score and performance parameters that contributed to the evaluation, even in an important way. According to our perspective, this study was analyzed by comparison between with OIC and non-OIC countries about their impact on the Halal tourism sector through 3 variables: - Top 10 OIC and non-OIC Halal tourism destinations, - Top Halal tourism expenditure source countries, - Halal tourism rank for World's top tourism destinations.

According to the (Mastercard \& Crescentrating, 2017) The analysis of " Top 10 OIC and nonOIC Halal tourism destinations " is conducted considering in particular four key strategic areas, able to highlight the aspects that tourist destinations must improve in order to become even more " Muslim friendly ". The key area's access (air connections and visa requirements are taken into consideration); communication (awareness of the halal travel market and its requirements); environment (family destinations and level of safety in general); services (catering and halal insurance, access to places of prayer, accommodation and airport facilities). The index offers parameters that depend on fundamental criteria for tourism agencies, travelers, travel service providers, economists, and specialists in the sector to understand the growth and health of the travel segment. The index is considered an excellent system for interested parties in the tourism sector, to understand how the Muslims' journey is conditioning the market. The deductive characteristics and initial analysis was conducted through comparison tables.

Global Muslim Travel Index (GMTI) 2017 is made up of several factors that constitute the Muslim tourists experience at a destination. The index looks at 11 criteria in 4 areas for a 
destination. Overall, 130 countries were studied and ranked in the GMTI 2017, which covers 48 OIC destinations and 82 non-OIC destinations (Mastercard \& Crescentrating, 2017).

According to the According to Global Islamic Economy Report 2016/2017, Muslim spending on the Halal travel market between countries is distributed as follows: \$108.8 Bn Muslim spending from the OIC market, $\$ 42.3$ billion of Muslim spending from the non-OIC market which $28 \%$ of total expenditure (Thomson Reuters \& Dinar Standard, 2016).

According to (UNWTO, 2017) France leads the list of the most visited destinations, followed by the United States, Spain, China, and Italy. Among the OIC Member States, Turkey is among the best tourist countries in the world.

\section{Discussion \& Finding}

The first finding in our research shows that the Islamic spending from the OIC market accounted for $78 \%$ of total spending. It is logical that the OIC countries are the main source of the Islamic tourism sector in the world, especially since $78 \%$ of the world's Muslims live in these countries. Muslim tourists and tourism expenditures are distributed unevenly among the OIC countries. the Gulf Cooperation Council countries located in the Middle East rich in natural resources account for $36 \%$ of the total in terms of spending, despite representing only $3 \%$ of the global Muslim population (Thomson Reuters \& Dinar Standard, 2016).

According to the results of the (Mastercard \& Crescentrating, 2017), 9 out of 10 countries are from OIC countries. Malaysia ranked first with a score of 82.5. Followed by the United Arab Emirates in second place with a score of 76.9 then Indonesia is in third place with a score of 72.6 (Table 1, OIC Destination). Actually, 9 out of the global top10 countries in Halal Tourism are members of the Organisation of Islamic Cooperation. on the other side countries as Singapore, Thailand, UK, South Africa, and Hong Kong got the top 5 non-OIC Halal tourism destinations global (Table 1, Non-OIC Destination). With a score of 67.3, Singapore Has overtaken Iran, which is one of the leading countries of Halal tourism among countries OIC members.

Table 1: Top 10 OIC and Non-OIC Halal Tourism Destinations

\begin{tabular}{|llllllll|}
\hline Rank & $\begin{array}{l}\text { GMTI } \\
\text { 2017 } \\
\text { Rank }\end{array}$ & $\begin{array}{l}\text { OIC } \\
\text { Destination }\end{array}$ & Score & Rank & $\begin{array}{l}\text { GMTI } \\
\mathbf{2 0 1 7} \\
\text { Rank }\end{array}$ & $\begin{array}{l}\text { Non-OIC } \\
\text { Destination }\end{array}$ & Score \\
\hline $\mathbf{1}$ & 1 & Malaysia & 82.5 & 1 & 10 & Singapore & 67.3 \\
\hline $\mathbf{2}$ & 2 & UAE & 76.9 & 2 & 18 & Thailand & 61.8 \\
\hline $\mathbf{3}$ & 3 & Indonesia & 72.6 & 3 & 20 & UK & 60.8 \\
\hline $\mathbf{4}$ & 4 & Turkey & 72.6 & 4 & 30 & $\begin{array}{l}\text { South } \\
\text { Africa }\end{array}$ & 53.6 \\
\hline $\mathbf{5}$ & 5 & $\begin{array}{l}\text { Saudi } \\
\text { Arabia }\end{array}$ & 71.4 & 5 & 31 & Hong Kong & 53.2 \\
\hline $\mathbf{6}$ & 6 & Qatar & 70.5 & 6 & 32 & Japan & 52.8 \\
\hline
\end{tabular}




\begin{tabular}{|llllllll|}
\hline $\mathbf{7}$ & 7 & Marocco & 68.1 & 7 & 33 & Taiwan & 52.4 \\
\hline $\mathbf{8}$ & 8 & Oman & 67.9 & 8 & 34 & France & 52.1 \\
\hline $\mathbf{9}$ & 9 & Bahrain & 67.9 & 9 & 36 & Spain & 48.8 \\
\hline $\mathbf{1 0}$ & 11 & Iran & 66.8 & 10 & 37 & USA & 48.6 \\
\hline
\end{tabular}

Source: MasterCard and Crescent Rating (2017)

Based on our reading of this research in general and according to some reports as regarding factors affecting in Halal tourism were selected 18 variables that they are a model for best practices for tourism Halal [ (COMCEC, 2016); (Thomson Reuters \& Dinar Standard, 2016); (Mastercard \& Crescentrating, 2017); (SESRIC, 2017); (Halaltrip, 2015); (International Religious Freedom Report, 2006)(AKYOL \& KILINÇ, 2014)

] and scientific research [ (AKYOL \& KILINÇ, 2014); (Duman, 2012); (Razalli et al., 2012), (Salleh et al., 2014) ] were taken into consideration the top 3 OIC Halal tourism destinations (Malaysia, UAE, and Indonesia) and were chosen 3 countries from top 10 non-OIC Halal tourism destinations (Singapore, Thailand, and UK) and compare them by showing similarities / differences and highlighting the best practices they have done to promote and develop the Halal tourism sector to give some proposal for destinations or countries that need to access such market.

Table: 2 the comparison between the top 3 OIC and non-OIC Halal tourism destinations

\begin{tabular}{|c|c|c|c|c|c|c|}
\hline & \multicolumn{3}{|c|}{ OIC } & \multicolumn{3}{|c|}{ Non-OIC } \\
\hline $\begin{array}{l}\text { Factors } \\
\text { Affecting in } \\
\text { Halal } \\
\text { Tourism }\end{array}$ & Malaysia & UAE & Indonesia & $\begin{array}{c}\text { Singapor } \\
\mathrm{e}\end{array}$ & Thailand & UK \\
\hline $\begin{array}{l}\text { 1- Food and } \\
\text { kitchen } \\
\text { Halal }\end{array}$ & $\begin{array}{l}\text { High level } \\
\text { (Diversity in } \\
\text { halal food) }\end{array}$ & $\begin{array}{l}\text { High level } \\
\text { (Variety of } \\
\text { halal food } \\
\text { in Arab and } \\
\text { foreign } \\
\text { cuisine) }\end{array}$ & $\begin{array}{l}\text { High level } \\
\text { (Halal } \\
\text { food is } \\
\text { available } \\
\text { for various } \\
\text { kitchens) }\end{array}$ & $\begin{array}{l}\text { High level } \\
\text { (There is } \\
\text { awareness } \\
\text { of the } \\
\text { concept of } \\
\text { Halal) }\end{array}$ & $\begin{array}{l}\text { Medium } \\
\text { level } \\
\text { (Recently, } \\
\text { the halal } \\
\text { food has } \\
\text { begun to be } \\
\text { taken care } \\
\text { of) }\end{array}$ & $\begin{array}{l}\text { Medium } \\
\text { level (I } \\
\text { recently } \\
\text { started } \\
\text { putting a } \\
\text { halal logo } \\
\text { in the } \\
\text { restaurant } \\
\text { ) }\end{array}$ \\
\hline $\begin{array}{l}\text { 2-Prayer } \\
\text { Facilities \& } \\
\text { Places of } \\
\text { prayer }\end{array}$ & $\begin{array}{l}\text { High level } \\
\text { (There are } \\
\text { prayer } \\
\text { facilities in } \\
\text { tourist areas } \\
\text { and public } \\
\text { places) }\end{array}$ & $\begin{array}{l}\text { High level } \\
\text { (Prayer } \\
\text { facilities } \\
\text { can be } \\
\text { found } \\
\text { easily in all } \\
\text { areas) }\end{array}$ & $\begin{array}{l}\text { High level } \\
\text { (There are } \\
\text { about } \\
800,000 \\
\text { mosques } \\
\text { spread } \\
\text { across all } \\
\text { the spots) }\end{array}$ & $\begin{array}{l}\text { Low level } \\
\text { (There are } \\
\text { about } 70 \\
\text { mosques } \\
\text { and some } \\
\text { small } \\
\text { places for } \\
\text { prayer in } \\
\text { shopping }\end{array}$ & $\begin{array}{l}\text { Medium } \\
\text { level } \\
\text { (There are } \\
3,405 \\
\text { mosques in } \\
\text { all } \\
\text { countries) }\end{array}$ & $\begin{array}{l}\text { Medium } \\
\text { level } \\
\text { (There } \\
\text { are } 345 \\
\text { mosques } \\
\text { in Great } \\
\text { Britain } \\
\text { that are a } \\
\text { large }\end{array}$ \\
\hline
\end{tabular}




\begin{tabular}{|c|c|c|c|c|c|c|}
\hline & & & & malls) & & $\begin{array}{l}\text { number } \\
\text { for a } \\
\text { Western } \\
\text { country) }\end{array}$ \\
\hline $\begin{array}{l}\text { 3-Services in } \\
\text { Ramadan }^{1}\end{array}$ & $\begin{array}{l}\text { High level } \\
\text { (Offers } \\
\text { suitable } \\
\text { tourist in the } \\
\text { month of } \\
\text { Ramadan) }\end{array}$ & $\begin{array}{l}\text { High level } \\
\text { (Hotels and } \\
\text { tourist } \\
\text { resorts } \\
\text { promote } \\
\text { great offers } \\
\text { and prices } \\
\text { suitable for } \\
\text { the month } \\
\text { of } \\
\text { Ramadan, } \\
\text { as well as } \\
\text { restaurants } \\
\text { and retail } \\
\text { outlets that } \\
\text { provide } \\
\text { additional } \\
\text { services) }\end{array}$ & $\begin{array}{l}\text { Medium } \\
\text { level } \\
\text { (There is } \\
\text { not much } \\
\text { focus on } \\
\text { attracting } \\
\text { Muslim } \\
\text { visitors } \\
\text { during } \\
\text { Ramadan) }\end{array}$ & $\begin{array}{l}\text { Medium } \\
\text { level } \\
\text { (Some } \\
\text { hotels } \\
\text { have } \\
\text { special } \\
\text { tour } \\
\text { packages } \\
\text { during the } \\
\text { month of } \\
\text { Ramadan) }\end{array}$ & $\begin{array}{l}\text { Medium } \\
\text { level (This } \\
\text { service is } \\
\text { not } \\
\text { available in } \\
\text { the most } \\
\text { important } \\
\text { hotels) }\end{array}$ & $\begin{array}{l}\text { Medium } \\
\text { level } \\
\text { (This } \\
\text { service } \\
\text { multiplies } \\
\text { in } \\
\text { mosques } \\
\text { during } \\
\text { Iftar }{ }^{2} \text { and } \\
\text { in some } \\
\text { restaurant } \\
\text { ) }\end{array}$ \\
\hline $\begin{array}{l}\text { 4-The toilet } \\
\text { consistent } \\
\text { with the } \\
\text { needs of } \\
\text { Muslims }\end{array}$ & $\begin{array}{l}\text { High level } \\
\text { (This service } \\
\text { is highly } \\
\text { available }\end{array}$ & $\begin{array}{l}\text { High level } \\
\text { (Convenien } \\
\mathrm{t} \\
\text { throughout } \\
\text { the UAE) }\end{array}$ & $\begin{array}{l}\text { Medium } \\
\text { level } \\
\text { (These } \\
\text { services } \\
\text { were } \\
\text { started } \\
\text { later) }\end{array}$ & $\begin{array}{l}\text { Medium } \\
\text { level (Not } \\
\text { available } \\
\text { on a large } \\
\text { scale) }\end{array}$ & $\begin{array}{l}\text { Medium } \\
\text { level (Some } \\
\text { hotels offer } \\
\text { this } \\
\text { service) }\end{array}$ & $\begin{array}{l}\text { Low level } \\
\text { (A few } \\
\text { hotels } \\
\text { offer this } \\
\text { service) }\end{array}$ \\
\hline $\begin{array}{l}\text { 5-Halal } \\
\text { certification }\end{array}$ & $\begin{array}{l}\text { High level } \\
\text { (There are } \\
\text { strong Halal } \\
\text { bodies and } \\
\text { certificates) }\end{array}$ & $\begin{array}{l}\text { High level } \\
\text { (The } \\
\text { Governmen } \\
\mathrm{t} \\
\text { introduced } \\
\text { the UAE } \\
\text { Halal } \\
\text { Standard to } \\
\text { monitor } \\
\text { and control } \\
\text { the } \\
\text { issuance of } \\
\text { the Halal } \\
\text { Certificate) }\end{array}$ & $\begin{array}{l}\text { High level } \\
\text { (Although } \\
\text { halal } \\
\text { certificates } \\
\text { in } \\
\text { restaurants } \\
\text { are not } \\
\text { fixed) }\end{array}$ & $\begin{array}{l}\text { High level } \\
\text { (There are } \\
\text { boards } \\
\text { that issue } \\
\text { Halal } \\
\text { certificate } \\
\text { s) }\end{array}$ & $\begin{array}{l}\text { Medium } \\
\text { level } \\
\text { (Depends } \\
\text { essentially } \\
\text { on the } \\
\text { UAE's } \\
\text { Gulf Halal } \\
\text { Center to } \\
\text { obtain the } \\
\text { certificate } \\
\text { of Halal } \\
\text { friendly) }\end{array}$ & $\begin{array}{l}\text { Medium } \\
\text { level } \\
\text { (Depends } \\
\text { essentiall } \\
\text { y on the } \\
\text { Halal } \\
\text { Food } \\
\text { Authority } \\
\text { (HFA) to } \\
\text { obtain the } \\
\text { certificate } \\
\text { of Halal } \\
\text { friendly) }\end{array}$ \\
\hline
\end{tabular}

${ }^{1}$ It is the month in which it is practiced fasting

${ }^{2}$ The evening meal when Muslims finish fasting 


\begin{tabular}{|c|c|c|c|c|c|c|}
\hline $\begin{array}{l}\text { 6-Halal } \\
\text { activities }\end{array}$ & $\begin{array}{l}\text { High level } \\
\text { (All tourist } \\
\text { places } \\
\text { consider } \\
\text { Halal } \\
\text { activities) }\end{array}$ & $\begin{array}{l}\text { Medium } \\
\text { level } \\
\text { (There are } \\
\text { a few } \\
\text { restaurants, } \\
\text { cafes and } \\
\text { internation } \\
\text { al hotels in } \\
\text { the UAE } \\
\text { that offer } \\
\text { Halal } \\
\text { services) }\end{array}$ & $\begin{array}{l}\text { High level } \\
\text { (All tourist } \\
\text { places } \\
\text { consider } \\
\text { Halal } \\
\text { activities) }\end{array}$ & $\begin{array}{l}\text { Low level } \\
\text { (It is } \\
\text { difficult to } \\
\text { find } \\
\text { tourist } \\
\text { destinatio } \\
\text { ns that } \\
\text { only } \\
\text { provide } \\
\text { Halal } \\
\text { services) }\end{array}$ & $\begin{array}{l}\text { Low level } \\
\text { (Traditional } \\
\text { tourism } \\
\text { activities } \\
\text { proliferate } \\
\text { which do } \\
\text { not take } \\
\text { into } \\
\text { considerati } \\
\text { on the } \\
\text { needs of } \\
\text { Muslims) }\end{array}$ & $\begin{array}{l}\text { Low level } \\
\text { (There } \\
\text { are many } \\
\text { bars } \\
\text { offering } \\
\text { alcohol, } \\
\text { which is } \\
\text { part of } \\
\text { the } \\
\text { country's } \\
\text { culture) }\end{array}$ \\
\hline $\begin{array}{l}\text { 7-Family- } \\
\text { Friendly } \\
\text { services \& } \\
\text { Shopping }\end{array}$ & $\begin{array}{l}\text { High level } \\
\text { (Offers } \\
\text { modern } \\
\text { shopping } \\
\text { with luxury } \\
\text { goods) }\end{array}$ & $\begin{array}{l}\text { High level } \\
\text { (It is an } \\
\text { attractive } \\
\text { shopping } \\
\text { area for } \\
\text { Muslims) }\end{array}$ & $\begin{array}{l}\text { Medium } \\
\text { level } \\
\text { (There is } \\
\text { not } \\
\text { enough } \\
\text { promotion } \\
\text { al policy) }\end{array}$ & $\begin{array}{l}\text { High level } \\
\text { (Shopping } \\
\text { malls are } \\
\text { a major } \\
\text { attraction) }\end{array}$ & $\begin{array}{l}\text { Medium } \\
\text { level } \\
\text { (Shopping } \\
\text { is not } \\
\text { available in } \\
\text { all tourist } \\
\text { areas) }\end{array}$ & $\begin{array}{l}\text { High } \\
\text { level } \\
\text { (London } \\
\text { is one of } \\
\text { the most } \\
\text { important } \\
\text { shopping } \\
\text { centers in } \\
\text { the world } \\
\text { for many } \\
\text { Muslims, } \\
\text { especially } \\
\text { the GCC } \\
\text { countries) }\end{array}$ \\
\hline $\begin{array}{l}\text { 8-Touristic } \\
\text { monuments, } \\
\text { Nature \& } \\
\text { Culture }\end{array}$ & $\begin{array}{l}\text { Medium } \\
\text { level } \\
\text { (Archaeologi } \\
\text { cal richness, } \\
\text { particularly } \\
\text { with regard } \\
\text { to Islamic } \\
\text { civilization } \\
\text { around the } \\
\text { country but } \\
\text { The tourist, } \\
\text { is based in } 2 \\
\text { or } 3 \text { cities } \\
\text { only) }\end{array}$ & $\begin{array}{l}\text { Low level } \\
\text { (High } \\
\text { summer } \\
\text { temperatur } \\
\text { es in the } \\
\text { UAE are } \\
\text { disturbing } \\
\text { many } \\
\text { tourists) }\end{array}$ & $\begin{array}{l}\text { High level } \\
\text { (It has } \\
\text { many to } \\
\text { offer to } \\
\text { tourists } \\
\text { from } \\
\text { natural, } \\
\text { heritage } \\
\text { and } \\
\text { historical } \\
\text { areas) }\end{array}$ & $\begin{array}{l}\text { High level } \\
\text { (Malaysia } \\
\text { is famous } \\
\text { for its } \\
\text { tourist } \\
\text { attractions } \\
\text { and } \\
\text { natural) }\end{array}$ & $\begin{array}{l}\text { medium } \\
\text { level (The } \\
\text { tourist } \\
\text { attractions } \\
\text { are located } \\
\text { in some } \\
\text { areas) }\end{array}$ & $\begin{array}{l}\text { High } \\
\text { level (UK } \\
\text { is famous } \\
\text { for its } \\
\text { tourist } \\
\text { attraction } \\
\mathrm{s} \text {, which } \\
\text { are a } \\
\text { great } \\
\text { attraction } \\
\text { for many } \\
\text { Muslims) }\end{array}$ \\
\hline
\end{tabular}




\begin{tabular}{|c|c|c|c|c|c|c|}
\hline $\begin{array}{l}\text { 9- } \\
\text { Accommodat } \\
\text { ion halal } \\
\text { friendly }\end{array}$ & $\begin{array}{l}\text { High level } \\
\text { (Hotel } \\
\text { services are } \\
\text { high in } \\
\text { meeting the } \\
\text { needs of the } \\
\text { Muslim } \\
\text { tourist) }\end{array}$ & $\begin{array}{l}\text { High level } \\
\text { (The ratio } \\
\text { increases of } \\
\text { hotels in } \\
\text { the United } \\
\text { Arab } \\
\text { Emirates } \\
\text { that do not } \\
\text { offer } \\
\text { alcohol and } \\
\text { non-halal } \\
\text { foods) }\end{array}$ & $\begin{array}{l}\text { Medium } \\
\text { level (This } \\
\text { service is } \\
\text { not } \\
\text { available } \\
\text { in all } \\
\text { areas) }\end{array}$ & $\begin{array}{l}\text { Low level } \\
\text { (A few of } \\
\text { the hotels } \\
\text { that offer } \\
\text { Halal } \\
\text { Friendly } \\
\text { are } \\
\text { especially } \\
\text { luxurious } \\
\text { ones) }\end{array}$ & $\begin{array}{l}\text { Low level } \\
\text { (Hotel Al } \\
\text { Meroz } \\
\text { recently } \\
\text { opened in } \\
\text { Bangkok } \\
\text { and was the } \\
\text { first halal } \\
\text { hotel that } \\
\text { has been } \\
\text { certified as } \\
\text { a Muslim } \\
\text { friendly } \\
\text { hotel by the } \\
\text { Halal } \\
\text { Center of } \\
\text { the UAE } \\
\text { Gulf) }\end{array}$ & $\begin{array}{l}\text { Low level } \\
\text { (This } \\
\text { service is } \\
\text { still not } \\
\text { available } \\
\text { as } \\
\text { required) }\end{array}$ \\
\hline $\begin{array}{l}10 \text { - } \\
\text { Separation of } \\
\text { areas } \\
\text { between men } \\
\text { and women }\end{array}$ & $\begin{array}{l}\text { Medium } \\
\text { level (This } \\
\text { service exists } \\
\text { but not } \\
\text { widely } \\
\text { due to the } \\
\text { difficulty of } \\
\text { their } \\
\text { application } \\
\text { occasionally) }\end{array}$ & $\begin{array}{l}\text { Medium } \\
\text { level (This } \\
\text { service } \\
\text { exists but } \\
\text { not widely } \\
\text { due to the } \\
\text { difficulty } \\
\text { of their } \\
\text { application } \\
\text { occasionall } \\
\text { y) }\end{array}$ & $\begin{array}{l}\text { Medium } \\
\text { level (This } \\
\text { service } \\
\text { exists but } \\
\text { not widely } \\
\text { due to the } \\
\text { difficulty } \\
\text { of their } \\
\text { applicatio } \\
\text { n } \\
\text { occasional } \\
\text { ly) }\end{array}$ & $\begin{array}{l}\text { Low level } \\
\text { (There is } \\
\text { still } \\
\text { absence } \\
\text { for this } \\
\text { service) }\end{array}$ & $\begin{array}{l}\text { Medium } \\
\text { level (There } \\
\text { are many } \\
\text { separate } \\
\text { health } \\
\text { resorts } \\
\text { between } \\
\text { men and } \\
\text { women } \\
\text { with } \\
\text { massagers } \\
\text { at the same } \\
\text { sex) }\end{array}$ & $\begin{array}{l}\text { Low level } \\
\text { (There is } \\
\text { still } \\
\text { absence } \\
\text { for this } \\
\text { service) }\end{array}$ \\
\hline $\begin{array}{l}\text { 11-flight } \\
\text { connection }\end{array}$ & $\begin{array}{l}\text { Low level } \\
\text { (Poor } \\
\text { connection } \\
\text { to important } \\
\text { destinations } \\
\text { of the world) }\end{array}$ & $\begin{array}{l}\text { High level } \\
\text { (Fly } \\
\text { Emirates } \\
\text { Is } \\
\text { working to } \\
\text { increase } \\
\text { tourists to } \\
\text { the United } \\
\text { Arab } \\
\text { Emirates) }\end{array}$ & $\begin{array}{l}\text { Low level } \\
\text { (Poor } \\
\text { connection } \\
\text { to } \\
\text { important } \\
\text { destination } \\
\text { s of the } \\
\text { world) }\end{array}$ & $\begin{array}{l}\text { Medium } \\
\text { level } \\
\text { (Medium } \\
\text { connectio } \\
\text { n to } \\
\text { important } \\
\text { destinatio } \\
\text { ns of the } \\
\text { world) }\end{array}$ & $\begin{array}{l}\text { High level } \\
\text { (Strong } \\
\text { connection } \\
\text { to } \\
\text { important } \\
\text { destinations } \\
\text { of the } \\
\text { world) }\end{array}$ & $\begin{array}{l}\text { High } \\
\text { level (has } \\
\text { the most } \\
\text { modern } \\
\text { airports } \\
\text { and many } \\
\text { aircraft } \\
\text { with a } \\
\text { wide } \\
\text { network } \\
\text { in many } \\
\text { countries } \\
\text { of the } \\
\text { world) }\end{array}$ \\
\hline 12-Airport & High level & High level & High level & Medium & High level & Medium \\
\hline
\end{tabular}




\begin{tabular}{|c|c|c|c|c|c|c|}
\hline Facilities & $\begin{array}{l}\text { (There are } \\
\text { many Halal } \\
\text { food \& } \\
\text { places of } \\
\text { prayer at } \\
\text { airports) }\end{array}$ & $\begin{array}{l}\text { (Many } \\
\text { airlines as } \\
\text { Emirates } \\
\text { Airlines } \\
\text { and Etihad } \\
\text { Airway } \\
\text { offer Halal } \\
\text { meals on } \\
\text { board) }\end{array}$ & $\begin{array}{l}\text { (There are } \\
\text { many } \\
\text { Halal food } \\
\& \text { places } \\
\text { of prayer } \\
\text { at airports) }\end{array}$ & $\begin{array}{l}\text { level } \\
\text { (There are } \\
\text { multi- } \\
\text { religious } \\
\text { prayer } \\
\text { rooms at } \\
\text { airports) }\end{array}$ & $\begin{array}{l}\text { (several } \\
\text { airports } \\
\text { offer prayer } \\
\text { rooms and } \\
\text { Halal } \\
\text { restaurants } \\
\text { such as } \\
\text { Bangkok's } \\
\text { Suvarnabhu } \\
\text { mi Airport, } \\
\text { Chiang Mai } \\
\text { Internationa } \\
\text { 1 Airport } \\
\text { and Phuket } \\
\text { Internationa } \\
\text { 1 Airport) }\end{array}$ & $\begin{array}{l}\text { level } \\
\text { (British } \\
\text { Airways } \\
\text { offers } \\
\text { halal } \\
\text { food) }\end{array}$ \\
\hline $\begin{array}{l}\text { 13-visa } \\
\text { requirements }\end{array}$ & $\begin{array}{l}\text { High level } \\
\text { (Visa is } \\
\text { granted free } \\
\text { of charge to } \\
\text { many } \\
\text { countries) }\end{array}$ & $\begin{array}{l}\text { Medium } \\
\text { level ( } \\
\text { Including } \\
\text { some } \\
\text { States) }\end{array}$ & $\begin{array}{l}\text { High level } \\
\text { (Visa is } \\
\text { granted } \\
\text { free of } \\
\text { charge to } \\
\text { many } \\
\text { countries) }\end{array}$ & $\begin{array}{l}\text { High level } \\
\text { (Visa is } \\
\text { granted } \\
\text { free of } \\
\text { charge to } \\
\text { many } \\
\text { countries) }\end{array}$ & $\begin{array}{l}\text { High level } \\
\text { (Visa is } \\
\text { granted free } \\
\text { of charge to } \\
\text { many } \\
\text { countries) }\end{array}$ & $\begin{array}{l}\text { Medium } \\
\text { level ( } \\
\text { Including } \\
\text { some } \\
\text { States) }\end{array}$ \\
\hline $\begin{array}{l}\text { 14-Media } \\
\text { activities \& } \\
\text { conferences }\end{array}$ & $\begin{array}{l}\text { High level } \\
\text { (The } \\
\text { government } \\
\text { has held } \\
\text { several } \\
\text { conferences } \\
\text { on Halal } \\
\text { tourism) }\end{array}$ & $\begin{array}{l}\text { Medium } \\
\text { level } \\
\text { (There is } \\
\text { still a lack } \\
\text { of } \\
\text { conference } \\
\text { and media } \\
\text { focus on } \\
\text { this type of } \\
\text { tourism) }\end{array}$ & $\begin{array}{l}\text { Medium } \\
\text { level } \\
\text { (There is } \\
\text { still a lack } \\
\text { of } \\
\text { conference } \\
\text { and media } \\
\text { focus on } \\
\text { this type } \\
\text { of } \\
\text { tourism) }\end{array}$ & $\begin{array}{l}\text { Medium } \\
\text { level } \\
\text { (There is } \\
\text { still a lack } \\
\text { of } \\
\text { conferenc } \\
\text { e and } \\
\text { media } \\
\text { focus on } \\
\text { this type } \\
\text { of } \\
\text { tourism) }\end{array}$ & $\begin{array}{l}\text { Low level } \\
\text { (Thailand is } \\
\text { a Buddhist } \\
\text { country in } \\
\text { which } \\
\text { tourism } \\
\text { marketing } \\
\text { is based on } \\
\text { the } \\
\text { traditions } \\
\text { and history } \\
\text { of this } \\
\text { religion) }\end{array}$ & $\begin{array}{l}\text { Low level } \\
\text { (There is } \\
\text { a large } \\
\text { absence } \\
\text { of } \\
\text { conferenc } \\
\text { es and } \\
\text { seminars } \\
\text { on this } \\
\text { subject ) }\end{array}$ \\
\hline $\begin{array}{l}\text { 15-Presence } \\
\text { of Islamic } \\
\text { banking and } \\
\text { finance }\end{array}$ & $\begin{array}{l}\text { High level } \\
\text { (Ranking } \\
\text { first in the } \\
\text { world in } \\
\text { terms of } \\
\text { Islamic } \\
\text { finance) }\end{array}$ & $\begin{array}{l}\text { High level } \\
\text { (Dubai is } \\
\text { the capital } \\
\text { of Islamic } \\
\text { finance) }\end{array}$ & $\begin{array}{l}\text { High level } \\
\text { (Ranking } \\
\text { ninth in } \\
\text { the world } \\
\text { in terms of } \\
\text { Islamic } \\
\text { finance) }\end{array}$ & $\begin{array}{l}\text { Low level } \\
\text { (There is } \\
\text { a great } \\
\text { absence of } \\
\text { this type } \\
\text { of } \\
\text { activity) }\end{array}$ & $\begin{array}{l}\text { Low level } \\
\text { (There is a } \\
\text { great } \\
\text { absence of } \\
\text { this type of } \\
\text { activity) }\end{array}$ & $\begin{array}{l}\text { Medium } \\
\text { level } \\
\text { (One of } \\
\text { the most } \\
\text { important } \\
\text { non- } \\
\text { Islamic } \\
\text { countries } \\
\text { evolution } \\
\text { of Islamic }\end{array}$ \\
\hline
\end{tabular}




\begin{tabular}{|lllllll|}
\hline & & & & & finance) \\
\hline $\begin{array}{l}\text { 16-The Role } \\
\text { of }\end{array}$ & High level & High level & High level & Medium & Medium & Medium \\
Government & (Give & (The & (The & level (The & level (The & level \\
in & priority to & Governmen & governme & governme & government & (The \\
Supporting & this market & t is & nt is & nt is & invested in & biggest \\
Halal & with the & strengtheni & working & working & the tourism & support \\
Tourism & establishmen & ng tourism & hard to & to attract & sector but & comes \\
& t of a & infrastructu & promote & tourists & focused & from the \\
& specialized & re) & Indonesia & and & recently on & Muslim \\
& center within & & as Halal & businessm & halal & communit \\
& the Ministry & & travel & en but has & tourism) & y) \\
& of Tourism) & & destination & not & & \\
& & ) & focused & & \\
& & & on halal & & \\
& & & tourism) & & \\
& & & & &
\end{tabular}

Source self elaboration

These factors were determined according to three criteria: Low level from 0 to 50, Medium level from 50 to 75 , High level from 75 to 100 .

After analyzing the table, it was found that OIC countries (Malaysia, UAE, and Indonesia) have excelled non-OIC countries (Singapore, Thailand, and UK) in 15 factors affecting in Halal tourism Out of 18 and it was equal in 3 factors.

Thanks to the numerous Muslim friendly services and a more developed ecosystem for Halal Tourism, OIC destinations (Malaysia, UAE, and Indonesia) have an advantage over non-OIC countries (Singapore, Thailand, and UK). However, there is a need to further develop strategic policies and plans in the OIC countries to develop this sector and to take advantage of the overall atmosphere and fertile ground that supports for such a kind of tourism and turn it into a competitive sector. In fact, the majority of the OIC countries need more basic requirements and standards to better attract Muslim tourists. On the other side, non-OIC countries (Singapore, Thailand, and UK) have made significant progress in providing a favorable environment for Muslim tourists by providing the important needs of Halal Friendly. These countries have a developed tourism sector characterized by integrated infrastructure and the quality and diversity of tourism services. Therefore, sometimes they need simple changes to provide suitable services for Muslim tourists and attract them.

As for the most visited countries in the world, although they occupied the top 10 positions in traditional tourism, while their positions were somewhat late in Halal tourism, Turkey is the only country that has achieved a leading position in Halal tourism followed by Thailand. To the Western countries, either France, Spain, the United States and Germany have occupied middle and close positions among them, China has moved away somewhat. Instead, Italy and Mexico have occupied positions far away. 
Table 3: Halal Torusim Rank for World's top tourism destinations

\begin{tabular}{|lllll|}
$\begin{array}{l}\text { Traditional } \\
\text { Tourism Rank }\end{array}$ & $\begin{array}{l}\text { International } \\
\text { Tourist Arrivals } \\
2016 \text { (million) }\end{array}$ & Destination & $\begin{array}{l}\text { Halal Tourism } \\
\text { Rank }\end{array}$ & $\begin{array}{l}\text { Score GMTI } \\
\mathbf{2 0 1 7}\end{array}$ \\
\hline $\mathbf{1}$ & 82.6 & France & 34 & 52.1 \\
\hline $\mathbf{2}$ & 75.6 & United State & 37 & 48.6 \\
\hline $\mathbf{3}$ & 75.6 & Spain & 36 & 48.8 \\
\hline $\mathbf{4}$ & 59.4 & China & 45 & 45.9 \\
\hline $\mathbf{5}$ & 52.4 & Italy & 62 & 42.2 \\
\hline $\mathbf{6}$ & 35.8 & United Kingdom & 20 & 60.0 \\
\hline $\mathbf{7}$ & 35.6 & Germany & 39 & 48.2 \\
\hline $\mathbf{8}$ & 32.1 & Mexico & 117 & 30.8 \\
\hline $\mathbf{9}$ & 32.6 & Thailand & 18 & 61.8 \\
\hline $\mathbf{1 0}$ & $\ldots$. & Turkey & 4 & 72.4 \\
\hline $\mathbf{5}$ & & & & \\
\hline
\end{tabular}

Source self elaboration

The Table 3 showing the GMTI 2017 rank for World's top tourism destinations with GMTI 2017 score for each country, at the level of Halal tourism sector for World's top tourism destinations, Turkey is the most visited by Muslim tourists followed by Thailand, United Kingdom. Countries such as France, Spain, the United States and Germany have a similar classification, with French superiority. China is a bit remote, while both Italy and Mexico have occupied late positions with very distant rankings.

It is very surprising that these countries, which have a very developed tourist sector and they have ranked first destinations in the world with regard to With traditional tourism, while for Halal tourism, they have obtained delayed positions, although some countries have recently tried to exploit this phenomenon by introducing Friendly Halal services in the sector Such as UK, France, and Spain, but their ranking in the Halal tourism sector is still inconsistent with their classifications in traditional tourism and do not fit into their natural positions. For example, a country such as Italy, which is the world's fifth most visited country, ranks 62th in the world in Halal tourism. This indicates that there is a large Italian absence compared to other tourist countries such as UK, France, and Spain, who hold much better positions at the same time they are similar with Bel Pease in the tourism infrastructure to a large extent.

After analysis Italy's factors affecting Halal tourism, It was observed that there was a general weakness in Muslim friendly services especially in the availability of Halal food and places to pray, there is also a total absence of conferences and seminars on Halal tourism and highlighted the needs of the Muslim tourist, which naturally helps the tourist infrastructure in Italy to understand this modern type of tourism with the exception of the city of Turin, which has held several conferences and seminars on the importance of tourism Halal tourism sector Italian, notably: Turin Islamic Economic Forum (TIEF). It is possible for Italy to benefit from this sector, similar to other European countries such as UK, focusing on the main requirements of 
Halal tourism and working on providing traditional Italian Halal food, which is considered one of the most important kitchens for many Muslims, and help the Italian tourism sector to understand this phenomenon through government institutions, universities and research centers, which have the largest role to explain the importance of Halal tourism and its ability to increase the income of any tourist institution.

\section{The Conclusion and Advances}

Halal tourism has shown that a new business opportunity in the world tourism sector represented by Islamic consumers. So there is a strong demand to satisfy. Despite different researches confirm that Halal tourism is a growing segment and therefore an important opportunity for the world tourism sector, especially for countries with a non-Muslim majority, in some countries and in particular the most visited ones, there is still a reluctant attitude on the part of all the actors operating in the tourism sector. Halal tourism must therefore be seen as a business opportunity for them, and not as a factor that overshadows non-Muslim tourists. The Study compared 3 OIC with 3 Non-OIC countries and results show that OIC countries outperform non-OIC countries in terms of spending and reception of tourists Muslim in this sector, with the knowledge that most member countries need an integrated development policy and lose the basic pillars and consistent plans to attract Muslim tourists better, while non-OIC countries have progressed significantly in this sector in terms of the implementation of the standards of halal, it is worth mentioning that these countries have a developed tourism sector needs simple adjustments to attract more Muslim tourists, Either the most visited countries in the world do not match their rankings with halal tourism occupy somewhat remote locations except Turkey. The study provided a framework for best practices of 16 variables to be used as a proposal for countries like Italy and Mexico that are still a destination not very frequented and with a weak structure of Muslim friendly services.

\section{REFERENCES}

Abuznaid, S. (2006). Islam and management: What can be learned? Thunderbird International Business Review, 48(1), 125-139. https://doi.org/10.1002/tie.20089

AKYOL, M., \& KILINÇ, Ö. (2014). INTERNET AND HALAL TOURISM MARKETING. Turkish Studies, 9, 17.

Ali, M. M. (1951). The religion of Islam, a comprehensive discussion of the sources, principles and practices of Islam. New Delhi, S. Chand. Retrieved from http://archive.org/details/religionofislamc00alim 
Almeida Garcia, F. (2014). A comparative study of the evolution of tourism policy in Spain and Portugal. Tourism Management Perspectives, 11, 34-50.

https://doi.org/10.1016/j.tmp.2014.03.001

Al-Quran (29:20). (n.d.). Surah Al-'Ankabut.

Battour, M., \& Ismail, M. N. (2016). Halal tourism: Concepts, practises, challenges and future. Tourism Management Perspectives, 19, 150-154. https://doi.org/10.1016/j.tmp.2015.12.008

Battour, M. M., Battor, M., \& Ismail, M. (2012). The Mediating Role of Tourist Satisfaction: A Study of Muslim Tourists in Malaysia: Journal of Travel \& Tourism Marketing: Vol 29, No 3. Journal of Travel \& Tourism Marketing, 279-297.

Battuta, I. (2004). Travels in Asia and Africa | 1325-1354 | Taylor \& Francis Group. London: Routledge. Retrieved from https://www.taylorfrancis.com/books/9781134285648

Bianchi, R. V. (2002). Towards a New Political Economy of Global Tourism. Sharpley, R. and D. Telfer (Eds.), 265-299.

Biancone, P. P. (2017). La Banca Islamica. Turin: G.Giappichelli Editore.

Buhalis, D., \& Costa, C. (2006). Tourism Management Dynamics: Trends, Management and Tools. Routledge.

Chookaew, S., chanin, O., Charatarawat, J., Sriprasert, P., \& Nimpaya, S. (2015). Increasing Halal Tourism Potential at Andaman Gulf in Thailand for Muslim Country. Journal of Economics, Business and Management, 3(7), 739-741.

https://doi.org/10.7763/JOEBM.2015.V3.277

COMCEC. (2016). Muslim Friendly Tourism: Understanding the Demand and Supply Sides In the OIC Member Countries. COMCEC COORDINATION OFFICE. Retrieved from http://www.mod.gov.tr/Lists/RecentPublications/Attachments/100/Muslim\%20Friendly\%20Tour ism\%20in\%20the\%200IC\%20Member\%20Countries.pdf

Duman, T. (2012). The Value of Islamic Tourism: Perspectives from the Turkish Experience. Islam and Civilisational Renewal (ICR), 3(4), 22.

Durbarry, R. (2004). Tourism and Economic Growth: The Case of Mauritius - Ramesh Durbarry, 2004. SAGE Journals. Retrieved from

http://journals.sagepub.com/doi/abs/10.5367/0000000042430962

El-Gohary, H. (2016). Halal tourism, is it really Halal? - ScienceDirect. Https://Ac.ElsCdn.Com/S2211973615001038/1-S2.0-S2211973615001038-Main.Pdf?_tid=60fcd99e-7cbc4f32-87e4-C3090cabf572\&acdnat=1532884511_807bf9584f8b1eacc631a5a43a79092c, 7. 
Halaltrip. (2015). Facilities for Muslims at the Busiest Airports in the Netherlands | HalalTrip. Retrieved July 1, 2018, from https://www.halaltrip.com/other/blog/facilities-for-muslims-at-thebusiest-airports-in-the-netherlands/

Haynes, C. (2010). 'A Trial for the Patience of Reason'? Grand Tourists and Anti-Catholicism after 1745. Journal for Eighteenth-Century Studies, 33(2), 195-208.

https://doi.org/10.1111/j.1754-0208.2010.00277.x

International Religious Freedom Report. (2006). US Department of State, Thailand. Retrieved July 1, 2018, from

https://web.archive.org/web/20100412115209/http://www.state.gov/g/drl/rls/irf/2006/71359.htm

Jaelani, A. (2017). Halal Tourism Industry in Indonesia: Potential and Prospects (SSRN

Scholarly Paper No. ID 2899864). Rochester, NY: Social Science Research Network. Retrieved from https://papers.ssrn.com/abstract=2899864

Jafari, J., \& Scott, N. (2014). Muslim world and its tourisms. Annals of Tourism Research, 44, 119. https://doi.org/10.1016/j.annals.2013.08.011

Mastercard, \& Crescentrating. (2017). Global Muslim Travel Index. Retrieved from https://newsroom.mastercard.com/asia-pacific/files/2017/05/Report-Mastercard-CrescentRatingGMTI-2017-20mb.pdf

Milliot, L., \& Blanc, F.-P. (1987). Introduction à l'étude du droit musulman. Sirey. Retrieved from https://www.africabib.org/rec.php?RID=048448621

Osman, F., Hussin, S., Yusof, R. N. R., Hashim, H., Aziz, Y. A., \& Nezakati, H. (2015). Special Needs of Muslim Family Tourists Across The Family Life Cycle: Stakeholders' Perspectives. Australian Journal of Basic and Applied Sciences, 5.

PewResearchCenter. (2011). The future of the global Muslim population: projections for 20102030. Retrieved from http://www.npdata.be/Data/Godsdienst/PEW/FutureGlobalMuslimPopulation-WebPDF.pdf

Razalli, M. R., Abdullah, S., \& Hassan, M. G. (2012). Developing a Model for Islamic Hotels: Evaluating Opportunities and Challenges, 5.

Sahih Al Bukhari. (2012). Sahih Al Bukhari. Dar Al Tasial. Retrieved from http://archive.org/details/WAQ144261new

Salleh, N. Z. M., Hamid, A. B. A., Hashim, N. H., \& Omain, S. Z. (2014). The Practice of Shariah-Compliant Hotel in Malaysia. International Journal of Trade, Economics and Finance, 26-30. https://doi.org/10.7763/IJTEF.2014.V5.335 
SESRIC. (2017). INTERNATIONAL TOURISM IN THE OIC COUNTRIES: PROSPECTS AND CHALLENGES 2017 realized by ORGANISATION OF ISLAMIC COOPERATION STATISTICAL ECONOMIC AND SOCIAL RESEARCH AND TRAINING CENTRE FOR ISLAMIC COUNTRIES (SESRIC). Retrieved from https://www.oicoci.org/docdown/?docID=1773\&refID=1071

Thomson Reuters, \& Dinar Standard. (2016). STATE OF THE GLOBAL ISLAMIC ECONOMY REPORT. Retrieved from http://ceif.iba.edu.pk/pdf/ThomsonReutersstateoftheGlobalIslamicEconomyReport201617.pdf

UNWTO. (2016). World Tourism Organization UNWTO Tourism Highlights: 2016 Edition. World Tourism Organization (UNWTO). https://doi.org/10.18111/9789284419029

UNWTO. (2017). World Tourism Organization UNWTO Tourism Highlights: 2017 Edition. World Tourism Organization (UNWTO). https://doi.org/10.18111/9789284419029

Warde, I. (2000). Islamic finance in the global economy. Edinburgh: Edinburgh University Press.

Yu, J., \& Lee, T. J. (2014). Impact of Tourists’' Intercultural Interactions Impact of Tourists' Intercultural Interactions. Journal of Travel Research, 53(2), 225-238. https://doi.org/10.1177/0047287513496467 